\title{
An Investigation of Pre-Service and In-Service Teachers' Perceptions of Teacher Quality in Turkey
}

\author{
Görsev SÖNMEZ BORAN* $\quad$ Burcu GÜRKAN** \\ Nuri Can AKSOY ${ }^{* * *}$
}

\begin{abstract}
Present study investigates the senior-level Turkish pre-service and inservice teachers' perceptions of teacher quality with a descriptive survey method. Data for this study were gathered through Teacher Quality Survey (TQS) and openended questions from 210 pre-service teachers enrolled in four different universities in Turkey and 147 in-service teachers from different majors. Results of the study showed that both pre-service and in-service teachers think that teachers' relationship with the students affect students' success and teachers should take the individual differences into consideration. Moreover, according to the pre-service teachers, teachers should know how to teach and assess what they teach, and they need to know time management. On the other hand, in-service teachers consider that teachers should follow current developments, should have the researcher identity and should understand students' needs and interests. Present study also suggested both academic and practical implications.
\end{abstract}

Keywords: In-service teacher, pre-service teacher, teacher education, teacher quality.

\footnotetext{
* Orcid ID: https://orcid.org/0000-0001-6726-3452, Assist. Prof. Dr., Hasan Kalyoncu University, Faculty of Education, Department of English Language Teaching, gorsevi@gmail.com

** Orcid ID: https://orcid.org/0000-0003-3942-6407, Assist. Prof. Dr., Hasan Kalyoncu University, Faculty of Education, Department of Elementary Education Teaching, burcu.gurkan@hku.edu.tr

*** Orcid ID: https://orcid.org/0000-0001-6087-8884, Assist. Prof. Dr., Hasan Kalyoncu University, Faculty of Education, Department of Elementary Education Teaching, ncan.aksoy@hku.edu.tr
} 


\section{INTRODUCTION}

In Turkey, teacher education officially started right after the foundation of Turkish Republic in 1923. In 1924, just after the announcement of republic, Mustafa Kemal Atatürk invited John Dewey to our country. The reason was asking his opinion about the best way of education and teacher training in a democratic social system (Ata, 2001). As a result of his suggestion, in 1925 a teacher education institution was founded in Konya with 16 students. This school moved to Ankara with the name of Gazi Institution of Education in 1926. From the very beginning of the Turkish Republic, various experts were invited to our country to investigate the problems in education and offer solutions. In 1933, on the invitation of Minister of Education, Dr. Reşit Galip, an education expert Prof. Dr. Albert Malche came to Turkey and published a report on the importance of establishing a university for teacher education. As a result, with the law dated 31.05.1933, \# 2547, Istanbul University was founded (Akyüz, 2009, p.381). From that year on the number of education faculties has increased continuously. Today, we have 90 education faculties and 5 educational science faculties all around Turkey. Currently, about 262 thousand pre-service teachers are studying at these faculties and about a million teachers graduated from these faculties are teaching in schools affiliated to the Ministry of National Education. This situation clearly shows the importance given to teacher education in Turkey.

Additionally, in the world, the large and rapid changes in our age make it necessary for people to live faster than before, to communicate more and to cooperate with people in different cultures and disciplines. In this time-domain difference, the development of high-level skills of individuals gains importance. Whilst such a change in the world is concerned, what should the qualifications of teachers who are one of the decisive elements in education be, have been taken up in the discussion agendas. However, the qualifications of teachers are possibly one of the most important variables of getting better learning services for learners.

It is also believed that professionally well-trained teachers can provide positive learning conditions for their students. For this reason, the existence of a continuous support provided to the teachers in professional development is of great importance (Seferoğlu, 2004). In the 'Global Education for All Report' published by UNESCO (2014), it is clearly stated that the student's success will be higher if teacher qualifications are at the optimum level. As stated by Darling-Hammond and Post (2000), an increase in the quality of education will be seen when teachers are supported.

\section{Literature Review}

In Turkey, changes in duty responsibilities and efforts to improve teacher qualifications to redefine roles are also examined by the Turkish National Ministry of Education (MoNE). For this reason, MoNE General Directorate of Teacher Training and Development published a text by updating the general qualifications of teachers' profession in December, 2017. There are 3 main competencies in the related text, 
namely; professional knowledge, professional skills, attitudes and values. Therefore, in Turkey, it is considered necessary and important to take the competency areas determined in this step for change by the teacher training institutions into account in order to go through the updates in the education system and to support the existing structure.

The field of the role of teacher and teacher qualifications on student success has received attention in the field of teacher education. As a result, research has shown that student learning is affected by a number of factors amongst which, teacher has an undeniable place. It is also a well-known fact that students who are exposed to high quality instruction, experience more and learn better (Darling-Hammond, 2000; Goldhaber \& Brewer, 2000). As generally acknowledged, the concept of teacher quality is considered to evolve over teaching and promoting teacher quality has a key role to improve education (Harris \& Sass, 2011). In the field, teacher quality has received immense attention. To specify, there is a vast amount of evidence regarding the significance of quality teachers for better learning (Hanushek, 1997; Okpala \& Ellis, 2000; Ozbek et al., 2007; Sanders \& Rivers, 1996, Yetim \& Goktas, 2004). Moreover, factors affecting and/or being affected by teacher quality have also been researched tremendously (Hanushek \& Rivkin, 2007; Harris \& Sass, 2010; Mincu, 2015; Thornton et al., 1991; Wiswall, 2013). And a final stance of research on teacher quality focuses on the perceptions of teacher candidates with regards to this specific concept (Okpala \& Ellis, 2000; Ozbek et al., 2007; Seker et al., 2005; Bozdogan et al., 2007).

Despite not having a clear-cut definition, as Shulman (1987) indicated in his groundbreaking article, it is suggested to include a range of knowledge base such as content, pedagogical, curriculum knowledge into the definition of teacher qualification. In a similar vein, Freeman et al. (1993) and Brophy (1991), in their studies, suggested that improving teachers' content knowledge and pedagogical skills facilitates classroom instruction of the teachers which in turn result in better student performance. Additionally, Slavin (2003) mentioned that high quality teachers should have the required subject matter knowledge, the skills to motivate students, time and classroom management skills. In another study, Sadker and Sadker (2003) focused on the necessity of knowing content very well and having verbal skills to transfer that knowledge to be called as quality teacher. Other than these characteristics, being experienced (Woolfolk, 2001), being good classroom managers (Onstein and Levin, 2003), being intentional teachers who are in continuous professional development (Eby, 1994; Sabers et al., 1995), being critical thinkers (Anderson et al., 1995; Floden and Klinzing, 1990), having problem solving skills and strategies (Duck, 2000) are the most common ones suggested as necessary to become a high quality teacher. Finally, Barber and Mourshed (2007) argues that the quality of an educational system cannot exceed the quality of teachers. It is thought that the variables such as the teachers' perception of their profession, the financial income of the teaching profession, the place in the order of the professions, the 
effect of the changing education system and the teacher training system are influenced (Semerci, Semerci, Eliüşük and Kartal, 2012).

As suggested strongly in the field of teacher education, teacher education process in the education faculties and teacher candidates' beliefs coming from their background or being shaped during their teacher education by the faculty academics have a strong impetus on their future teaching career. In other words, teacher quality is a concept that evolves over the teaching career starting from teacher education in education faculties with the facilitation of the teacher educators who are all academics. Owing to this fact and the common agreement on the effect of teachers' perceptions on their actual teaching, the concept of teacher quality has been researched widely both nationally and internationally. However, the comparison of perceptions of senior level pre-service teachers who are about to start their teaching career and experienced in-service teachers has received no attention to the knowledge of the researchers. Therefore, this study especially aims at filling this gap in the literature.

\section{METHOD}

Given all the above-mentioned research findings, present study aims at investigating the aim of the research is to investigate the perceptions of the senior-level pre-service teachers and in-service teachers regarding teacher qualifications required for education in the changing world. This research is a quantitative study designed according to the descriptive survey model. Survey models are research approaches aimed at describing a past or present situation in its present form and determining specific characteristics of a group (Karasar, 2006; Büyüköztürk et al., 2014). In this research, teacher qualifications were aimed to be depicted.

\section{Setting and Participants}

The research is carried out in 2017-2018 fall and spring semesters with senior preservice teachers in 4 different universities (Bayburt, Çukurova, Gazi, Hasan Kalyoncu) located in different geographical regions of our country and with teachers whose majors are different and who are teaching in different levels. The number and the demographic information of the participants are given in the following table.

\section{Table 1.}

Pre-service Teachers' demographic information

\begin{tabular}{|c|c|c|c|}
\hline \multicolumn{4}{|c|}{ Pre-service Teachers $(N=210)$} \\
\hline $\begin{array}{l}\text { Hasan Kalyoncu } \\
\text { University }(\mathrm{N}=70)\end{array}$ & $\begin{array}{l}\text { Çukurova University } \\
(\mathrm{N}=50)\end{array}$ & $\begin{array}{l}\text { Gazi University } \\
(\mathrm{N}=50)\end{array}$ & $\begin{array}{l}\text { Bayburt University } \\
(\mathrm{N}=40)\end{array}$ \\
\hline \multicolumn{4}{|l|}{ Department } \\
\hline $\begin{array}{l}\text { ELT } \\
(\mathrm{N}=67)\end{array}$ & $\begin{array}{l}\text { Primary Education } \\
(\mathrm{N}=73)\end{array}$ & $\begin{array}{l}\text { Psychological G } \\
(\mathrm{N}=70)\end{array}$ & dance and Counselling. \\
\hline
\end{tabular}


Table 2.

In-service Teachers' demographic information

\begin{tabular}{|c|c|c|c|c|}
\hline \multicolumn{5}{|c|}{ Teaching Level of In-service Teachers $(N=147)$} \\
\hline $\begin{array}{l}\text { Nursery School } \\
(\mathrm{N}=10)\end{array}$ & $\begin{array}{l}\text { Primary School } \\
(\mathrm{N}=79)\end{array}$ & $\begin{array}{l}\text { Secondary } \\
\text { School }(N=26)\end{array}$ & $\begin{array}{l}\text { High School } \\
(\mathrm{N}=16)\end{array}$ & $\begin{array}{l}\text { University } \\
(\mathrm{N}=16)\end{array}$ \\
\hline \multicolumn{5}{|c|}{ Teaching Experience of In-service Teachers } \\
\hline $\begin{array}{l}1-5 \text { years } \\
(\mathrm{N}=75)\end{array}$ & $\begin{array}{l}\text { 6-10 years } \\
(\mathrm{N}=28)\end{array}$ & $\begin{array}{l}\text { 11-15 years } \\
(\mathrm{N}=18)\end{array}$ & $\begin{array}{l}16 \text { +years } \\
(\mathrm{N}=26)\end{array}$ & \\
\hline
\end{tabular}

\section{Data Collection and Analysis}

Within this study, Teacher Quality Survey (TQS) was used to investigate the perceptions of senior level pre-service teachers and in-service teachers regarding teacher quality. The questionnaire consisted of two sections. The first part was to gather data on teacher quality through open-ended questions to triangulate the data in the second section. The second section contained a 24-item, 5-point Likert-type scale. The first 8 items of the questionnaire were adopted from Okpala and Ellis (2005) and the other 20 questions were constructed after a thorough literature review on teacher quality. Since the native language of all participants is Turkish, the questionnaire was developed and administered in Turkish. In order to test the construct validity of the scale, it was assigned to five different external scrutiny. Following their feedback, some items were deleted and the final 23-item survey was piloted on 120 pre-service teachers one year before the real administration. The participants were requested to identify their level of agreement with each item by selecting one of the choices ranging from $5=$ Strongly Agree to $1=$ Strongly Disagree. Cronbach's index of internal consistency was used to check the reliability of the scale. And the reliability coefficient was found .84 which is accepted as a quite high value (Cresswell, 2003). In the real administration, the Cronbach's Alpha value was found .81 .

40 randomly selected answers to all three open-ended questions in the first section of the survey were analyzed through content analysis and the frequency of each item was found. 23-item second section was, on the other hand analyzed through descriptive statistical analysis on SPSS.

\section{FINDINGS}

Descriptive analysis results of pre-service and in-service teachers' perceptions regarding teacher qualifications are given in tables 3 and 4 . These results show that pre-service teachers give the utmost importance to the teachers' knowledge of content, assessment and pedagogy. On the other hand, they do not think that student success is related to 
teacher's academic level, the quality of the university he graduated from, knowledge and experience. In-service teachers, in contrast, think that teacher quality is mostly related to teachers' professional development and researcher identity. As it was the case with the pre-service teachers' perceptions, in-service teachers also do not think that teacher quality is related to the academic level of the teacher or the quality of the university he graduated from.

\section{Table 3.}

Descriptive analysis of pre-service teachers' perceptions of teacher quality

\begin{tabular}{llcc}
\hline \multicolumn{2}{l}{ Most Preferred Items } & & \\
\hline Item & Statement & M & SD \\
\hline 1 & & 4.51 & .786 \\
8 & Students will be successful if teachers know how to teach. & 4.54 & .723 \\
9 & Teacher's approach to students affect student success. & 4.52 & .702 \\
18 & Teachers should know how to assess what they teach. & 4.54 & .687 \\
19 & Teachers should know time management. & 4.52 & .754 \\
& Teachers should keep the individual differences among & & \\
\hline Least Preferred Items & & \\
\hline 4 & Teachers with MA degree cause better learning of students. & 2.85 & 1.125 \\
5 & If the teacher knows the subject well, students learn better. & 3.73 & 1.095 \\
6 & Teacher's relationship with students is more important than & 3.79 & .940 \\
& his knowledge about subject. & & \\
20 & Teacher's quality depends on his experience. & 3.26 & 1.223 \\
& Teacher's quality depends on the university he graduated & 2.70 & 1.345
\end{tabular}




\section{Table 4.}

Descriptive analysis of in-service teachers' perceptions of teacher quality

\begin{tabular}{|c|c|c|c|}
\hline \multicolumn{4}{|c|}{ Most Preferred Items } \\
\hline $\begin{array}{l}\text { Item } \\
\text { No }\end{array}$ & Statement & $\mathbf{M}$ & SD \\
\hline 14 & Teachers should follow current developments in the field & 4.81 & .501 \\
\hline 19 & $\begin{array}{l}\text { Teachers should keep the individual differences among } \\
\text { students in mind. }\end{array}$ & 4.79 & .486 \\
\hline 11 & A quality teacher should have the researcher identity. & 4.78 & .507 \\
\hline 8 & Teacher's approach to students affect student success. & 4.76 & .501 \\
\hline 17 & $\begin{array}{l}\text { Teacher should keep the students' needs and interest in mind } \\
\text { while preparing the instruction. }\end{array}$ & 4.74 & .469 \\
\hline \multicolumn{4}{|c|}{ Least Preferred Items } \\
\hline 23 & $\begin{array}{l}\text { Teacher's quality depends on the university he graduated } \\
\text { from. }\end{array}$ & 2.41 & 1.287 \\
\hline 4 & Teachers with MA degree cause better learning of students. & 2.51 & 1.088 \\
\hline 20 & Teacher's quality depends on his experience. & 2.89 & 1.111 \\
\hline 5 & If the teacher knows the subject well, students learn better. & 3.68 & 1.129 \\
\hline 2 & Verbal ability of the teacher is the key to student success. & 3.90 & .858 \\
\hline
\end{tabular}

The results of the content analysis of the forty randomly selected responses of each party given to three open-ended questions in the survey triangulated the quantitative analysis results. These results are depicted under three different categories each of whose codes are given in different tables (Table 5-6-7). The categories are; (1) participants' perceptions of teacher quality (table 5), (2) participants' perceptions of teacher characteristics (table 6), and participants' perceptions of factors affecting teacher quality (table 7). As 


\section{Table 5.}

Findings about perceptions of teacher quality

\begin{tabular}{|c|c|c|c|c|c|}
\hline \multicolumn{3}{|c|}{ Pre-service Teachers } & \multicolumn{3}{|c|}{ In-service Teachers } \\
\hline $\begin{array}{l}\text { Professional } \\
\text { Knowledge }\end{array}$ & $\begin{array}{l}\text { Professional } \\
\text { Ability }\end{array}$ & $\begin{array}{l}\text { Attitude \& } \\
\text { Value }\end{array}$ & $\begin{array}{l}\text { Professional } \\
\text { Knowledge }\end{array}$ & $\begin{array}{l}\text { Professional } \\
\text { Ability }\end{array}$ & $\begin{array}{l}\text { Attitude \& } \\
\text { Value }\end{array}$ \\
\hline $\begin{array}{l}\text { Content } \\
\text { Knowledge } \\
(\mathrm{f}=23)\end{array}$ & $\begin{array}{l}\text { Using } \\
\text { appropriate } \\
\text { method } \\
(\mathrm{f}=9)\end{array}$ & $\begin{array}{l}\text { Being } \\
\text { respectful to } \\
\text { students } \\
(\mathrm{f}=11)\end{array}$ & $\begin{array}{l}\text { Content } \\
\text { Knowledge } \\
(\mathrm{f}=5)\end{array}$ & $\begin{array}{l}\text { Teaching } \\
\text { appropriate } \\
\text { to student } \\
\text { level }(\mathrm{f}=3)\end{array}$ & $\begin{array}{l}\text { Being open } \\
\text { to } \\
\text { innovations } \\
(\mathrm{f}=13)\end{array}$ \\
\hline $\begin{array}{l}\text { Pedagogical } \\
\text { Knowledge } \\
(\mathrm{f}=6)\end{array}$ & $\begin{array}{l}\text { Time and } \\
\text { class } \\
\text { managemen } \\
\mathrm{t}(\mathrm{f}=5)\end{array}$ & $\begin{array}{l}\text { Being } \\
\text { devoted } \\
(\mathrm{f}=11)\end{array}$ & $\begin{array}{l}\text { Pedagogical } \\
\text { Knowledge } \\
(\mathrm{f}=5)\end{array}$ & $\begin{array}{l}\text { Guiding } \\
\text { students } \\
(\mathrm{f}=2)\end{array}$ & $\begin{array}{l}\text { Being a } \\
\text { researcher } \\
(\mathrm{f}=12)\end{array}$ \\
\hline $\begin{array}{l}\text { Knowing } \\
\text { student } \\
\text { needs }(\mathrm{f}=6)\end{array}$ & $\begin{array}{l}\text { Improving } \\
\text { students' } \\
\text { social skills } \\
(\mathrm{f}=1)\end{array}$ & $\begin{array}{l}\text { Being open } \\
\text { to } \\
\text { professional } \\
\text { developmen } \\
\mathrm{t} \text { and } \\
\text { research } \\
(\mathrm{f}=6)\end{array}$ & $\begin{array}{l}\text { Knowing } \\
\text { student } \\
\text { needs }(\mathrm{f}=1)\end{array}$ & $\begin{array}{l}\text { Using } \\
\text { materials } \\
\text { effectively } \\
(\mathrm{f}=2)\end{array}$ & $\begin{array}{l}\text { Having good } \\
\text { communicati } \\
\text { on skills } \\
(\mathrm{f}=7)\end{array}$ \\
\hline \multirow[t]{3}{*}{$\begin{array}{l}\text { General } \\
\text { culture } \\
(\mathrm{f}=1)\end{array}$} & & $\begin{array}{l}\text { Inspiring } \\
\text { students } \\
(\mathrm{f}=6)\end{array}$ & & $\begin{array}{l}\text { Using } \\
\text { technology } \\
\text { effectively } \\
(\mathrm{f}=2)\end{array}$ & $\begin{array}{l}\text { Being hard- } \\
\text { working ( } \mathrm{f}= \\
\text { 2) }\end{array}$ \\
\hline & & $\begin{array}{l}\text { Psychologic } \\
\text { al } \\
\text { competence } \\
(\mathrm{f}=3)\end{array}$ & & & \\
\hline & & $\begin{array}{l}\text { Having } \\
\text { Communicat } \\
\text { ive Skills } \\
(\mathrm{f}=3)\end{array}$ & & & \\
\hline
\end{tabular}


Table 6.

Findings about perceptions of teacher characteristics

\begin{tabular}{|c|c|c|c|}
\hline Pre-service Teachers & & In-service Teachers & \\
\hline Attitude \& Values & & Attitude \& Values & \\
\hline $\begin{array}{l}\text { Strong } \\
\text { communication } \\
\text { skills }(\mathrm{f}=16)\end{array}$ & Patience $(\mathrm{f}=8)$ & Patience $(\mathrm{f}=18)$ & Devoted $(\mathrm{f}=10)$ \\
\hline Respect $(f=11)$ & Trust $(\mathrm{f}=3)$ & $\begin{array}{l}\text { Open to innovations } \\
(\mathrm{f}=16)\end{array}$ & Tolerant $(\mathrm{f}=6)$ \\
\hline $\begin{array}{l}\text { Democracy \& } \\
\text { Fairness }(\mathrm{f}=10)\end{array}$ & Researcher $(f=3)$ & Researcher $(\mathrm{f}=16)$ & Sincere $(f=4)$ \\
\hline Tolerance $(f=5)$ & Disciplined $(\mathrm{f}=2)$ & $\begin{array}{l}\text { Conscientious } \\
(\mathrm{f}=16)\end{array}$ & Empathy (f=3) \\
\hline Conscientious $(\mathrm{f}=3)$ & & Loving $(\mathrm{f}=10)$ & Disciplined $(\mathrm{f}=3)$ \\
\hline
\end{tabular}

Table 7.

Findings about perceptions of factors affecting teacher quality

\begin{tabular}{|c|c|c|c|c|c|}
\hline \multicolumn{3}{|c|}{ Pre-service Teachers } & \multicolumn{2}{|c|}{ In-service Teachers } & \multirow[b]{2}{*}{$\begin{array}{l}\text { Work } \\
\text { Conditions }\end{array}$} \\
\hline Personal & Environmental & $\begin{array}{l}\text { Work } \\
\text { Conditions }\end{array}$ & Personal & Environmental & \\
\hline $\begin{array}{l}\text { Teacher } \\
\text { education } \\
(\mathrm{f}=16)\end{array}$ & $\begin{array}{l}\text { Social } \\
\text { Environment } \\
(\mathrm{f}=15)\end{array}$ & $\begin{array}{l}\text { Physical } \\
\text { conditions } \\
(\mathrm{f}=3)\end{array}$ & $\begin{array}{l}\text { Teacher } \\
\text { Education } \\
(\mathrm{f}=17)\end{array}$ & $\begin{array}{l}\text { Work } \\
\text { environment } \\
(\mathrm{f}=4)\end{array}$ & $\begin{array}{l}\text { Students } \\
(\mathrm{f}=5)\end{array}$ \\
\hline $\begin{array}{l}\text { Being } \\
\text { innovative } \\
(\mathrm{f}=8)\end{array}$ & $\begin{array}{l}\text { Family } \\
\text { Environment } \\
(\mathrm{f}=2)\end{array}$ & $\begin{array}{l}\text { Students } \\
(\mathrm{f}=2)\end{array}$ & $\begin{array}{l}\text { Being } \\
\text { innovative } \\
(\mathrm{f}=7)\end{array}$ & $\begin{array}{l}\text { Family } \\
\text { environment } \\
(\mathrm{f}=3)\end{array}$ & $\begin{array}{l}\text { Parents } \\
(\mathrm{f}=5)\end{array}$ \\
\hline $\begin{array}{l}\text { Personal } \\
\text { relations } \\
(\mathrm{f}=3)\end{array}$ & $\begin{array}{l}\text { Work } \\
\text { Environment } \\
(\mathrm{f}=2)\end{array}$ & $\begin{array}{l}\text { Income } \\
(\mathrm{f}=1)\end{array}$ & $\begin{array}{l}\text { Personality } \\
(\mathrm{f}=4)\end{array}$ & $\begin{array}{l}\text { Social } \\
\text { environment } \\
(\mathrm{f}=1)\end{array}$ & $\begin{array}{l}\text { Income } \\
(\mathrm{f}=4)\end{array}$ \\
\hline $\begin{array}{l}\text { Content } \\
\text { knowledge } \\
(\mathrm{f}=3)\end{array}$ & & & $\begin{array}{l}\text { Philosophy } \\
(\mathrm{f}=3)\end{array}$ & & $\begin{array}{l}\text { School } \\
\text { principles } \\
(\mathrm{f}=3)\end{array}$ \\
\hline $\begin{array}{l}\text { Pedagogical } \\
\text { Knowledge }\end{array}$ & & & $\begin{array}{l}\text { Critical } \\
\text { Thinking }\end{array}$ & & $\begin{array}{l}\text { Conditions } \\
(\mathrm{f}=3)\end{array}$ \\
\hline
\end{tabular}


$(\mathrm{f}=3)$

Class

Management

( $\mathrm{f}=3$ ) $(\mathrm{f}=2)$

Content

Knowledge

( $\mathrm{f}=2$ )

Family

relations

( $\mathrm{f}=2$ )

\section{RESULTS, DISCUSSIONS AND SUGGESTIONS}

The quantitative findings regarding the participants' perceptions of teacher quality showed that both pre-service and in-service teachers think that teachers' relationship with the students affect students' success and teachers should take the individual differences into consideration. Moreover, according to the pre-service teachers, teachers should know how to teach and assess what they teach, and they need to know time management. On the other hand, in-service teachers consider that teachers should follow current developments, should have the researcher identity and should understand students' needs and interests.

On the contrary, the findings of the survey showed that neither pre-service nor inservice teachers think that teachers' content knowledge is effective on student success, teachers' MA degree has an impact on students' better learning, teacher quality depends on the university being graduated from or the experience of the teacher. Pre-service teachers, furthermore, think that teachers' relationship with students is more important than their content knowledge. In-service teachers also believe that teachers' verbal skills is not the key to the student success.

In addition to the above mentioned quantitative results, content analysis results of responses given to the open-ended questions by both parties indicated that most of the perceptions regarding the concept of teacher quality are gathered under the themes of professional knowledge (e.g. content knowledge, pedagogical competence, understanding student needs) and professional ability (e.g. teaching appropriate to the level of the students) and attitude and values (e.g. open to innovations, being respectful to students, researcher identity, being devoted).

Furthermore, both parties' ideas regarding the characteristics quality teachers should have were grouped under the theme of attitudes and values. Some of these ideas are; strong communication skills, being loving and respectful, democracy and fairness, being patience, being open to innovations, being in continuous professional development, conscientious.

Finally, pre-service teachers considered that teacher education, student psychology, income, social, family and work environment are the factors affecting teacher quality. Similarly, according to in-service teachers, teacher education, being innovative, work 
and family environment, income and parents are the factors that have impact on the quality of teachers.

When all these findings are considered, the finding that teacher education affects teacher quality does not coincide with the research findings made by Barber \& Mourshed (2007). Researchers are convinced that the education system and the education received have no impact on quality. On the other hand, findings about both parties' perceptions of qualified teachers are in parallel with findings that are thought to be influenced by variables such as the level of income of the teaching profession, its place in the order of professions, the effect of the changing education system and the teacher training system. (Semerci et al., 2012).

Another similarity between findings and literature in the context of professional knowledge and skills is that teachers' content knowledge and pedagogical knowledge, time and classroom management skills are identified by participants among factors that increase the quality of teachers (Freeman et al., 1993, Brophy, 1991, Slavin, 2003).Finally, the results of this study about the factors such as having critical thinking skills (Anderson et al., 1995, Floden and Klinzing, 1990), being willing and interested teacher who is in constant professional development (Eby, 1994; Sabers ve ark., 1995) and having problem solving skills and strategies (Duck, 2000) are all in line with the literature.

To conclude, pre-service teachers and in-service teachers consider that teacher quality is based on the pedagogical knowledge (teaching method technical knowledge and skill, measurement and evaluation knowledge and skills, classroom management, material preparation and use etc.), their researcher identity, personality characteristics and their relationship with students.

Considering the effects of the professional skills, content knowledge and pedagogical factors on the perceptions of teacher quality, the implications for administrators, teacher training academicians and educational institutions developing the teacher education curriculum can be listed as follows; Curriculums of education faculties need to be prepared and implemented in a way that provides opportunities for preservice teachers for the development and application of these qualities. It is necessary for the academicians to inform the preservice teachers about which qualifications have a positive effect on student achievement and to be both role models and to prepare course contents with emphasis on these qualities in order to reinforce these qualifications. Results also show that when the value given to the teacher is increased both materially and spiritually, the teachers' qualifications will increase. For this reason, the authorities are required to take the necessary precautions to make these improvements. 


\section{References}

Akyüz, Y. (2009). Türk Eğitim Tarihi. Pegem Akademi, Ankara.

Ata, B. (1924). Türk basını ışığında Amerikalı eğitimci John Dewey'nin Türkiye seyahati. Gazi Üniversitesi Gazi Eğitim Fakültesi Dergisi, 21(3), 193-207.

Bozdoğan, A. E., Aydın, D., \& Yıldırım, K. (2007). Öğretmen adaylarının öğretmenlik mesleğine ilişkin tutumları. Ahi Evran Üniversitesi Kırşehir Eğitim Fakültesi Dergisi, 8(2), 209-222.

Büyüköztürk, Ş., Kılıç-Çakmak E., Akgün, Ö. E., Karadeniz, Ş. \& Demirel, F. (2008). Bilimsel Araştırma Yöntemleri (Geliştirilmiş 2. baskı). Ankara: Pegem A Yayıncılık.

Cresswell. J. (2002). Research design: qualitative, quantitative and mixed methods Approaches (2nd ed.). Thousand Oaks, CA: Sage.

Darling-Hammond, L. (2000). Teacher quality and student achievement: A review of State policy evidence. Journal of Education Policy Analysis, 8(1), 114-120.

Duck, L. (2000). The ongoing professional journey, Educational Leadership, 57(8), 43-45.

Eby, J. (1994). Reflective planning, teaching and evaluation: K-12. New York: Merrill.

Freeman, D., \& Richards, J. C. (1993). Conceptions of teaching and the education of second language teachers. Tesol Quarterly, 27(2), 193-216.

Goldhaber, D. \& Brewer, D. (2000). Does teacher certification matter? High school Teacher certification status and student achievement. Educational Evaluation and Policy Analysis, 22(2),129-146.

Hanushek, E. (1997). Assessing the effects of school resources on student performance: An update. Educational Evaluation and Policy Analysis, 100(1), 84-117.

Hanushek, E. A. \& Rivkin, S. G. (2007). Pay, working conditions and Teacher quality, Future of Children, 17(1), 69-86.

Harris, D. N., \& Sass, T. R. (2010). Teacher training, teacher quality and student achievement. Journal of public economics, 95(7-8), 798-812.

Karasar, N. (2006). Bilimsel Araştırma Yöntemi. Ankara: Nobel Yayın Dağıtım.

Mincu, M. E. (2015). Teacher quality and school improvement: what is the role of research?. Oxford Review of Education, 41(2), 253-269.

Okpala, C. O., \& Ellis, R. (2000). The perceptions of college students on teacher quality: A Focus on teacher qualifications. Education, 126(2), 374-383.

Ornstein, A. C., \& Levine, D. U. (2003). Foundations of education (8th ed.). Boston, MA: Houghton Mifflin.

Özbek, R., Kahyaoğlu, M., \& Özgen, N. (2007). Evaluation of candidate teachers' opinions on teaching profession. Afyon Kocatepe University Journal of Social Sciences, 9(2), 221-232.

Sabers, D., Selby, L., \& Nolan, P. (1995). Computers empower students with special Needs. Educational Leadership, 53(2), 82-84.

Sanders, W. L., \& Rivers, J. C. (1996). Cumulative and residual effects of teachers on future student academic achievement. In Education Trust, Thinking K-16: Good teaching matters: How well qualified teachers can close the gap.

Seferoglu, G. (2004). A study of alternative English teacher certification practices in Turkey. Journal of Education for Teaching, 30(2), 151-159. 
Seker, H., Deniz, S., \& Görgen, İ. (2005). Tezsiz yüksek lisans öğretmen adaylarının öğretmenlik yeterlikleri üzerine değerlendirmeleri. Kuram ve uygulamada eğitim yönetimi, 42, 237-253.

Semerci, C., Semerci, N., Eliüşük, A., \& Kartal, E. (2012). Öğretmenlik mesleğinin gündemine ilişkin öğretmen görüşleri (Bartın ili örneği). Bartın Üniversitesi Eğitim Fakültesi Dergisi, 1(1), 2240.

Shulman, L. (1987). Knowledge and teaching: Foundations of the new reform. Harvard Educational Review, 19(2), 4-14.

Wiswall, M. (2013). The dynamics of teacher quality, Journal of Public Economics, 100.

Yetim, A. A., \& Göktaş, Z. (2004). Öğretmenin mesleki ve kişisel yetenekleri, Kastamonu Eğitim Dergisi, 12(2), 541-550. 